\title{
Problematika Ilmu Falak Kontemporer : Studi Kiblat di Rumah Makan Pinggir Jalan Lintas Kabupaten/Kota se Sumatera Barat
}

\author{
Hendri $^{*}$, Zul Efendi ${ }^{2}$ \\ ${ }^{1,2}$ Institut Agama Islam Negeri Bukittinggi \\ 1*Email: hendri@iainBukittinggi.ac.id
}

\begin{abstract}
This study aims to describe the qibla of musala in roadside restaurants across districts in West Sumatera. This includes the the comprehension, the methods that used, and the accuration of qibla. This research found the methode the owner used to determine the qibla direction, first, by estimating the direction, using sunset direction, following the nearby buildings. Second, by compass usage, android smartphone qibla direction software. Thus that it affects the accuracy of the qibla direction based on rasdhul qibla. So $15 \%$ of the qibla in the roadside restaurant musala is inaccurate or 3 musala out of 17 musala. This were caused by the lack of understanding, knowledge and information on the qibla by roadside restaurant owners across districts and cities in West Sumatra
\end{abstract}

Keywords : Islamic Astronomi, Contemporary, Restaurant, Qibla.

\begin{tabular}{l}
\hline Abstrak \\
\hline Penelitian ini bertujuan untuk mendeskripsikan kiblat musala di \\
Rumah makan pinggir jalan lintas Kabupaten kota di Sumatera \\
Barat. Ini meliputi bagaimana pemahaman, metode yang \\
digunakan, bagaimana akurasi kiblatnya. Penelitian ini \\
menemukan cara dalam menentukan arah kiblat, pertama \\
dengan perkiraan saja, arah matahari terbenam, mengikuti \\
bangunan sekitar. Kedua menggunakan kompas, aplikasi \\
software arah kiblat android. Sehingga berpengaruh terhadap \\
akurasi arah kiblatnya berdasarkan rasdhul kiblat. Maka 15\% \\
kiblat di musala Rumah makan pinggir jalan tidak akurat atau 3 \\
musala dari 17 musala. Hal ini dikarenakan minimnya \\
pemahaman, pengetahuan serta informasi kiblat oleh pemilik \\
Rumah makan pinggir jalan lintas Kabupaten Kota di Sumatera \\
Barat.
\end{tabular}

Kata Kunci : Ilmu Falak, Kontemporer, Rumah Makan, Kiblat.

Artikel Info

Received:

24 Februari 2021

Revised:

23 Maret 2021

Accepted:

26 April 2021

Published:

08 Juni 2021 


\section{A. Pendahuluan}

Sumatera Barat merupakan daerah yang mayoritas umat Islam dengan filosofinya Adat Basandi Syara',Syara' Basandi Kitabullah. ${ }^{1}$ Hal ini diperkuat dengan adanya sarana dan prasarana peribadatan seperti Masjid dan Musala. ${ }^{2}$ Hal ini juga tak terkecuali pada rumah makan dikarenakan orang Sumatera Barat dikenal dengan Rumah Makan Padang. ${ }^{3}$

Orang Padang identik dengan Rumah makan. ${ }^{4}$ Di zaman kontemporer ini pemilik Rumah makan Padang selain menyediakan tempat makan juga menyediakan tempat ibadah bagi pelanggannya atau pengunjungnya. ${ }^{5} \mathrm{Hal}$ ini banyak diminati dikarenakan selain tempat makan juga sebagai sarana peribadatan, ${ }^{6}$ tetapi di satu sisi perlu juga dipertanyakan atau diragukan keberadaan

${ }^{1}$ Yunia Wardi. Abror Abror and Okki Trinanda, 'Service Excellent Rumah Makan Padang Dalam Perspektif Wisata Islami', International Journal of Community Service Learning, 3.3 (2019), 133.

${ }^{2}$ Yunia Wardi. Abror Abror and Okki Trinanda, 'Service Excellent Rumah Makan Padang Dalam Perspektif Wisata Islami', International Journal of Community Service Learning, 3.3 (2019), 134.

${ }^{3}$ Arsyi Kharisma And Prima Sukmadianti Putri, 'Upaya Rumah Makan Padang Dalam Menciptakan Kepuasan Pelanggan', OSF Preprints, 2018 <https://doi.org/https://doi.org/10.31219/osf.io/au4fg $>$.

${ }^{4}$ Oktavianus Oktavianus, Ike Revita, and Khairil Anwar, 'Lanskap Linguistik Nilai Budaya Pada Rumah Makan Minang ( Linguistic Landscape of Cultural Values at Rumah Makan Minang )', Mozaik Humaniora, 19.1 (2019), 90-108. musala yang ada di rumah makan terkait arah kiblatnya.

Rumah makan ${ }^{7}$ adalah suatu bisnis warung makan atau Rumah makan atau restoran yang menjual atau menghidangkan berbagai ragam kuliner atau masakan Minangkabau yang berasal dari Sumatera Barat $^{8}$. Rumah makan ini amat terkenal di Indonesia bahkan dunia dan disukai oleh berbagai kalangan serta bermacam etnis dan bangsa karena masakan atau makannya yang lezat serta daya adaptasinya yang bisa menyesuaikan diri dengan lidah atau selera masyarakat di mana rumah makan ini berada. ${ }^{9}$ Rumah makan Padang di luar Sumatera Barat menghidangkan masakan yang tidak terlalu pedas, berbeda dengan rumah makan yang ada di tanah kelahirannya sendiri ${ }^{10}$. Usaha rumah makan ini hadir

${ }^{5}$ Reny dkk, 'Strategi Pengembangan Bisnis Rumah Makan Padang Di Sekitar Lingkar Kampus Ibi Kosgoro 1957', Mediastima, 26.1 (2020), 18-25.

${ }^{6}$ Madia Patra Ismar, 'Rumah Makan Padang Sebuah Narasi Pertunjukan Budaya: Studi Kasus Rumah Makan Padang Simpang Raya', Urban, 2.1 (2019), 41-47.

${ }^{7}$ Henny Welsa, "Budaya Minangkabau Dan Implementasi Pada Manajemen Rumah Makan Padang Di Yogyakarta," Ekuitas (Jurnal Ekonomi Dan Keuangan) 1, no. 2 (2017), h. 181.

${ }^{8}$ Kharisma And Putri, "Upaya Rumah Makan Padang Dalam Menciptakan Kepuasan Pelanggan."

9 Trinanda, 'Service Excellent Rumah Makan Padang Dalam Perspektif Wisata Islami’,.

10 Arief Herdiansah, Yani Sugiyani, and Ri Sabti Septarini, "Penerapan Pembelajaran E-Bisnis Siswa Pkbm Paja Mandiri Pada Pembuatan Prototipe Sistem Rumah Makan Masakan Padang Kutabumi," JIKA (Jurnal Informatika) 4, no. 2 (2020), h. 39,. 


\section{AL-MARSHAD: JURNAL ASTRONOMI ISLAM DAN ILMU-ILMU BERKAITAN \\ ISSN 2442-5729 (print) || ISSN 2598-2559 (online) \\ http://jurnal.umsu.ac.id/index.php/almarshad \\ DOI: //doi.org/10.30596/jam.v7i1.6494 || Vol. 7, No. 1 Juni 2021}

dalam berbagai tingkatan sosial mulai dari warung Padang kaki lima yang harganya terjangkau oleh kalangan bawah, rumah makan yang menargetkan kalangan menengah sebagai sasaran pasarnya, hingga restoran mewah yang menargetkan kalangan atas dengan harga yang cukup tinggi sesuai fasilitas yang disediakan. ${ }^{11}$

Menghadap kiblat merupakan salah satu syarat sahnya salat ${ }^{12}$. Maka dalam artikel ini penulis akan menggali pengetahuan pemilik rumah makan pinggir jalan lintas Kabupaten, Kota di Sumatera Barat.

Berdasarkan pengecekan arah kiblat menggunakan kompas dan metode Rasdhul kiblat harian pada tanggal 28 April 2021 di Rumah makan Pangek Situjuah ditemukan deviasi arah kiblat musalanya $\pm 3^{0}$. Selanjutnya penulis juga melakukan pengecekan arah kiblat di musala Rumah makan Lamun Ombak yang beralamat di jalan lintas PadangBukittinggi, berdasarkan pengecekan tersebut penulis mendapatkan deviasi arah kiblatnya \pm 10 dari azimutnya ${ }^{13}$

${ }^{11}$ Fahmi Fatwa Rosyadi Satria Hamdani et al., "An Accuracy Test of Qibla Direction Measurement of Mosques and Prayer Rooms" 409, no. SoRes 2019 (2020). h. 82-87.

${ }^{12}$ Ridho Kimura Soderi, “Al-Marshad: Jurnal Astronomi Islam Dan Ilmu-Ilmu Berkaitan," Jurnal Astronomi Islam Dan Ilmu-Ilmu Berkaitan 5729, no. June (2018), h.46-66.
Maka dari hal diatas penulis ingin mengetahui bagaimana pemahaman, metode yang digunakan dalam menentukan arah kiblat di musala rumah makan pinggir jalan lintas Kabupaten Kota di Sumatera Barat serta bagaimana akurasi arah kiblatnya. Selanjutnya tujuan dalam penelitian ini adalah untuk mengetahui pemahaman pemilik Rumah makan pinggir jalan tentang arah kiblat, mengetahui metode yang digunakan serta akurasi arah kiblat musala yang ada di Rumah makan pinggir jalan lintas Kabupaten Kota se-Sumatera Barat.

\section{B. Metode Penelitian}

Penelitian ini termasuk pada jenis penelitian lapangan (filed Research) ${ }^{14}$, di mana penelitian ini bermaksud untuk mengetahui pemahaman, metode penentuan arah kiblat di musala atau tempat salat yang digunakan oleh pemilik Rumah makan pinggir jalan lintas kabupaten kota di Sumatera Barat serta akurasinya. Penelitian ini dilakukan dengan analisis kualitatif ${ }^{15}$ yang dianalisis dan diklarifikasi terkait arah kiblat musala yang ada di Rumah makan pinggir jalan lintas kabupaten kota di Sumatera Barat,

13 Azimut kiblat daerah pariaman $294^{\circ} 20^{\prime}$, penulis mendapatkan azimut kiblat yang ada di mushala rumah makan lamun ombak sebesar $295^{\circ} 30^{\prime}$

${ }^{14}$ Hamdani and others.

15 A B D Karim Faiz, "moderasi fiqh penentuan arah kiblat: Akurasi Yang Fleksibel," Of Islamic Law 1, no. 1 (2020), h. 83-99. 


\section{AL-MARSHAD: JURNAL ASTRONOMI ISLAM DAN ILMU-ILMU BERKAITAN \\ ISSN 2442-5729 (print) || ISSN 2598-2559 (online) \\ http://jurnal.umsu.ac.id/index.php/almarshad \\ DOI: //doi.org/10.30596/jam.v7i1.6494 || Vol. 7, No. 1 Juni 2021}

metode dan akurasi dari arah kiblatnya serta kondisi bangunan awal musala. Dalam tulisan ini dilakukan analisis sosiologi ${ }^{16}$ terhadap masyarakat terkhusus pengelola rumah makan pinggir jalan lintas Kabupaten kota Sumatera Barat terhadap pemahaman, metode dan akurasi arah kiblat. Untuk dapat menganalisis akurasi dari kiblat musala di restoran/ Rumah makan pinggir jalan, penelitian ini menggunakan kompas kiblat, rashdul kiblat untuk mengetahui sudut kiblatnya dan menggunakan perhitungan trigonometri untuk mengetahui ${ }^{17}$ sudut deviasi kiblat di musala di rumah makan tersebut.

Adapun metode pengumpulan data berupa observasi, wawancara dan dokumentasi ${ }^{18}$. Penelitian ini dibatasi pada 17 musala yang ada di Rumah makan pinggir jalan lintas Kabupaten kota di Sumatera Barat

Adapun analisis data dalam penelitian ini meliputi beberapa tahap. Langkah awal dimulai dengan menelaah seluruh data yang diperoleh dari berbagai sumber seperti observasi, wawancara dan dokumentasi yang sudah didapatkan di lapangan berupa data

16 Anisah Budiwati, "Akurasi Arah Kiblat Masjid Di Ruang Publik," JSSH (Jurnal Sains Sosial Dan Humaniora) 2, no. 1 (2018), h. 159.

${ }^{17}$ Riza Afrian Mustaqim, “Analisis Metode Penentuan Arah Kiblat Masjid Agung Baitul Makmur Meulaboh Aceh Barat (2020), h. 181-94.

18 Mohd. Kalam Daud and Muhammad Kamalussafir, "Akurasi Arah Kiblat Komplek Pemakaman Ditinjau Menurut Kaidah Trigonometri pengecekan arah kiblat di musala Rumah makan pinggir jalan lintas Kabupaten Kota Sumatera Barat $^{19}$. Selanjutnya membuat abstraksi dengan membuat pernyataan. Setelah itu data direduksi kemudian ditampilkan dengan uraian singkat dan langkah selanjutnya melakukan kategorisasi dan verification / conclusion ${ }^{20}$.

\section{Hasil dan Pembahasan}

\section{Hasil Penelitian}

\section{Pemahaman pemilik Rumah makan pinggir jalan lintas}

\section{Kabupaten Kota di Sumatera Barat}

Dalam menguraikan pemahaman pemilik Rumah makan pinggir jalan lintas Kabupaten Kota Sumatera Barat, namun sebelumnya penulis akan mendeskripsikan profil dan sejarah pembangunan musala Rumah makan pinggir jalan lintas Kabupaten Kota seSumatera Barat kemudian diberikan kesimpulan atas pemahaman terhadap pemahaman pemilik Rumah makan pinggir jalan lintas Kabupaten Kota Sumatera Barat. Berikut ini lokasi

(Studi Kasus Di Kecamatan Syiah Kuala Kota Banda Aceh)," SAMARAH: Jurnal Hukum Keluarga Dan Hukum Islam 2, no. 2 (2019), h. 502.

19 Dini Selasi, "Jurnal Inklusif: Jurnal Pengkajian," Jurnal Inklusif 4, no. 1 (2019), h. 33-46.

20 Hosen, dkk, et al., "Akurasi Arah Kiblat Pemakaman Desa Ponteh Kecamatan Galis Kabupaten Pamekasan," Al-Marshad: Jurnal Astronomi Islam Dan Ilmu-Ilmu Berkaitan 5, no. 2 (2019), h. 146-76, 
penelitian yang ditunjukkan oleh Tabel 1 .

Dibawah ini :

Tabel 1. Lokasi Penelitian

\begin{tabular}{|c|c|c|c|}
\hline No & $\begin{array}{l}\text { Rumah } \\
\text { makan/ } \\
\text { restoran }\end{array}$ & $\begin{array}{c}\text { Tahun } \\
\text { Pendirian }\end{array}$ & alamat \\
\hline 1. & $\begin{array}{l}\text { Musala } \\
\text { Rumah } \\
\text { makan } \\
\text { Pongek } \\
\text { Situjuah } \\
\end{array}$ & 2000 & $\begin{array}{l}\text { Jalan raya } \\
\text { Bukittinggi- } \\
\text { Payakumbuh }\end{array}$ \\
\hline 2. & $\begin{array}{l}\text { Musala } \\
\text { Rumah } \\
\text { makan } \\
\text { Terang Bulan }\end{array}$ & 1995 & $\begin{array}{l}\text { Jalan raya } \\
\text { Payakumbuh- } \\
\text { Pekanbaru }\end{array}$ \\
\hline 3. & $\begin{array}{l}\text { Musala } \\
\text { Rumah } \\
\text { makan } \\
\text { Ombak } \\
\text { Pangkalan } \\
\end{array}$ & 2005 & $\begin{array}{l}\text { Jalan raya } \\
\text { Pangkalan- } \\
\text { Pekanbaru }\end{array}$ \\
\hline 4. & $\begin{array}{l}\text { Musala } \\
\text { Rumah } \\
\text { makan Uwan }\end{array}$ & 2000 & $\begin{array}{l}\text { Jalan raya } \\
\text { Payakumbuh- } \\
\text { Pekanbaru }\end{array}$ \\
\hline 5. & $\begin{array}{l}\text { Musala } \\
\text { Rumah } \\
\text { makan Ranah } \\
\text { Minang }\end{array}$ & 2002 & $\begin{array}{l}\text { Jalan raya } \\
\text { Tanjung pati- } \\
\text { Pekanbaru }\end{array}$ \\
\hline 6. & $\begin{array}{l}\text { Musala } \\
\text { Rumah } \\
\text { makan Aia } \\
\text { Badarun }\end{array}$ & 2003 & $\begin{array}{ll}\text { Jalan raya } \mathrm{X} \\
\text { Koto- } \\
\text { Bukittinggi }\end{array}$ \\
\hline 7. & $\begin{array}{l}\text { Musala } \\
\text { Rumah } \\
\text { makan } \\
\text { Mandeh } \\
\text { Kanduang } \\
\text { (Pesisir } \\
\text { Selatan) }\end{array}$ & 2002 & $\begin{array}{lr}\text { Jalan raya } \\
\text { Pesisir-Padang }\end{array}$ \\
\hline 8. & $\begin{array}{l}\text { Musala } \\
\text { Rumah } \\
\text { makan Bunda }\end{array}$ & 2002 & $\begin{array}{lr}\text { Jalan raya } \\
\text { Painan-Padang }\end{array}$ \\
\hline 9. & $\begin{array}{l}\text { Musala } \\
\text { Rumah } \\
\text { makan } \\
\text { Lamun } \\
\text { Ombak } \\
\end{array}$ & 2000 & $\begin{array}{l}\text { Jalan raya } \\
\text { Pariaman- } \\
\text { Padang }\end{array}$ \\
\hline 10. & $\begin{array}{l}\text { Musala } \\
\text { Rumah } \\
\text { makan Pasia } \\
\text { Piaman }\end{array}$ & 2015 & $\begin{array}{l}\text { Jalan raya } \\
\text { Padang- } \\
\text { Bukittinggi }\end{array}$ \\
\hline 11. & $\begin{array}{l}\text { Musala } \\
\text { Rumah } \\
\text { makan } \\
\text { Umega } \\
\text { Gunung }\end{array}$ & 1976 & $\begin{array}{l}\text { Jalan raya } \\
\text { Gunung } \\
\text { Medan-Sungai } \\
\text { Deras }\end{array}$ \\
\hline
\end{tabular}

\begin{tabular}{|c|c|c|c|}
\hline & Medan & & \\
\hline 12. & $\begin{array}{l}\text { Musala } \\
\text { Rumah } \\
\text { makan Sari } \\
\text { Ratu } \\
\text { Sijunjung }\end{array}$ & 2007 & $\begin{array}{l}\text { Jalan raya } \\
\text { Sijunjung- } \\
\text { Darmasraya }\end{array}$ \\
\hline 13. & $\begin{array}{l}\text { Musala } \\
\text { Rumah } \\
\text { makan Salero } \\
\text { Kampung }\end{array}$ & 2014 & $\begin{array}{l}\text { Jalan raya } \\
\text { Solok- } \\
\text { Sawahlunto }\end{array}$ \\
\hline 14. & $\begin{array}{l}\text { Musala } \\
\text { Rumah } \\
\text { makan } \\
\text { pondok } \\
\text { Tarapuang } \\
\end{array}$ & 1997 & $\begin{array}{l}\text { Jalan raya } \\
\text { Pasaman- } \\
\text { Bukittinggi }\end{array}$ \\
\hline 15 & $\begin{array}{l}\text { Musala } \\
\text { Rumah } \\
\text { makan Kapau } \\
\text { Simpang } \\
\text { Empat } \\
\text { Pasaman } \\
\text { Barat }\end{array}$ & 2000 & $\begin{array}{l}\text { Jalan raya } \\
\text { Simpang } \\
\text { Empat- } \\
\text { Bukittinggi }\end{array}$ \\
\hline 16 & $\begin{array}{l}\text { Musala } \\
\text { Rumah } \\
\text { makan Angin } \\
\text { Berembus }\end{array}$ & 1995 & $\begin{array}{lr}\text { Jalan raya } \\
\text { Ombilin-Solok }\end{array}$ \\
\hline 17. & $\begin{array}{l}\text { Musala } \\
\text { Rumah } \\
\text { makan } \\
\text { Pondok Kita } \\
\text { Darmasraya }\end{array}$ & 2000 & $\begin{array}{l}\text { Jalan raya } \\
\text { Darmasraya- } \\
\text { Sijunjung }\end{array}$ \\
\hline
\end{tabular}
menggambarkan lokasi atau tempat penelitian yang penulis jadikan sampel dalam penelitian ini. Selanjutnya pada Tabel 2. diperlihatkan distribusi pemahaman terkait dengan penentuan arah kiblat

Tabel 2. Distribusi pemahaman arah kiblat dan metode penentuan arah kiblatnya

\begin{tabular}{lll}
\hline No & $\begin{array}{l}\text { Pemahaman pemilik Rumah } \\
\text { makan tentang arah kiblat }\end{array}$ & Jml \\
\hline 1. & Arah kiblat mengarah ke barat & 2 \\
\hline 2. & $\begin{array}{l}\text { mengikuti arah kiblat dengan } \\
\text { bangunan disekitar }\end{array}$ & 1 \\
\hline 3. & Ditentukan oleh ahlinya & 3 \\
\hline 4. & Mengikuti arah matahari terbenam & 1 \\
\hline 5. & Menggunakan kompas & 3 \\
\hline 6. & Menggunakan aplikasi & 7 \\
\hline & Jumlah & 17
\end{tabular}




\section{AL-MARSHAD: JURNAL ASTRONOMI ISLAM DAN ILMU-ILMU BERKAITAN \\ ISSN 2442-5729 (print) || ISSN 2598-2559 (online) \\ http://jurnal.umsu.ac.id/index.php/almarshad \\ DOI: //doi.org/10.30596/jam.v7i1.6494 || Vol. 7, No. 1 Juni 2021}

Berdasarkan Tabel. 2 di atas, pemilik Rumah makan mengetahui arah kiblat. Bahwasanya ketika salat menghadap ke kiblat/ namun secara teori (ilmu astronomi) $)^{21}$ bagaimana sebenarnya pengukuran dan penentuan arah kiblat mereka kurang paham, sehingga banyak yang memanfaatkan perangkat lunak atau aplikasi arah kiblat berbasis android. Berangkat dari pemahaman mereka, ada responden yang menjawab pada dasarnya agama Islam ini mudah, ${ }^{22}$ maka untuk menentukan arah kiblat, cukup menggunakan aplikasi android yang sudah dibuat dan dirancang sedemikian akurat ${ }^{23}$.

2. Metode penentuan arah kiblat di musala yang digunakan pemilik Rumah makan pinggir jalan lintas Kabupaten Kota di Sumatera Barat

Penentuan arah kiblat dapat ditentukan dengan berbagai metode, berikut ini pada Tabel 3. Ditunjukkan metode yang digunakan dalam penentuan arah kiblat musala pemilik Rumah makan pinggir jalan lintas Kabupaten Kota di Sumatera Barat

Tabel 3. Metode penentuan arah kiblat musala yang digunakan

\begin{tabular}{lll}
\hline No & Metode & Akurasi \\
\hline
\end{tabular}

${ }^{21}$ Nurul Arifin, “Integrasi Teks-Teks Syar'I Yang Terkait Dengan Arah Kiblat Dalam Konteks Astronomi," Elfalaky 4, no. 1 (2020), h. 73-92.

${ }^{22}$ Muhammad Yunus, "Hadis Tentang Arah Kiblat: Kritik Pemikiran Ali Mustafa Yaqub," Jurnal Al-Irfani STAI Darul Kamal VI, no. 1 (2020), h. 8-17.

\begin{tabular}{lll}
\hline 1. & Kompas & $\begin{array}{l}\text { Jika jauh dari medan } \\
\text { magnetik, maka } \\
\text { hasilnya akurat }\end{array}$ \\
\hline 2. & Arah barat matahari & Tidak akurat \\
\hline 3. & $\begin{array}{l}\text { Arah } \\
\text { terbenam }\end{array}$ \\
\hline 4. & Aplikasi & $\begin{array}{l}\text { Perlu pengujian } \\
\text { untuk akurat }\end{array}$ \\
\hline 5. & $\begin{array}{l}\text { Ditentukan } \\
\text { ahlinya }\end{array}$ & Akurat \\
\hline 6 & $\begin{array}{l}\text { Arah bangunan } \\
\text { sekitar }\end{array}$ & Tidak akurat \\
\hline
\end{tabular}

Berdasarkan Tabel 3. di atas, dapat diketahui metode penentuan arah kiblat di musala Rumah makan pinggir jalan lintas Kabupaten Kota di Sumatera Barat yaitu dengan kompas (3 responden), berpatokan dengan arah barat ( 2 responden), berpedoman ke arah matahari terbenam (1 responden), menggunakan aplikasi (7 responden), ditentukan oleh ahlinya (3 responden) dan berpatokan kepada bangunan sekitar (1 responden).

Dari Tabel 3. di atas, kebanyakan pemilik rumah makan pinggir jalan lintas Kabupaten Kota di Sumatera Barat menentukan arah kiblat dengan aplikasi arah kiblat berbasis android hal ini dikarenakan aplikasi arah kiblat pada HP android mudah didapatkan dan digunakan dengan mengunduh aplikasi arah kiblat di google playstore $^{24}$ kemudian di atur arah ponsel

23 Ulyatun Nisa and Titin Suprihatin, "Uji Akurasi Aplikasi Sun Qibla Dalam Penentuan Arah Kiblat Praktis," 2021, h. 11-15.

24 Sudirman Lubis, "Design Of Qiblat Direction Using Hmc 58831 Sensor" 2 (2021), H. 17884. 


\section{AL-MARSHAD: JURNAL ASTRONOMI ISLAM DAN ILMU-ILMU BERKAITAN \\ ISSN 2442-5729 (print) || ISSN 2598-2559 (online) \\ http://jurnal.umsu.ac.id/index.php/almarshad \\ DOI: //doi.org/10.30596/jam.v7i1.6494 || Vol. 7, No. 1 Juni 2021}

hingga jarum kompas yang ada pada aplikasi tersebut sejajar dengan ikon arah $\mathrm{Ka}$ 'bah atau dengan arah kiblat musala tersebut. Sebagian ada yang mempercayai tenaga ahli seperti dari KEMENAG untuk menentukan arah kiblatnya dengan harapan lebih meyakinkan pengurus untuk menentukannya. ${ }^{25}$

3. Akurasi arah kiblat musala Rumah makan pinggir jalan lintas Kabupaten Kota di Sumatera Barat

Berdasarkan survei yang dilakukan berikut ini adalah data deviasi Arah Kiblat Musala Rumah makan Pinggir jalan lintas Kabupaten di Sumatera Barat yang ditunjukkan oleh Tabel 4.

Tabel 4. Deviasi Arah Kiblat Musala Rumah makan Pinggir jalan lintas Kabupaten di Sumatera Barat

\begin{tabular}{|c|c|c|c|c|}
\hline No & $\begin{array}{c}\text { Rumah } \\
\text { makan/ } \\
\text { restoran }\end{array}$ & $\begin{array}{l}\text { Kib } \\
\text { lat }\end{array}$ & $\begin{array}{c}\text { Kemelencen } \\
\text { gan }\end{array}$ & $\begin{array}{c}\text { Metode } \\
\text { pengukur } \\
\text { an ulang }\end{array}$ \\
\hline 1. & $\begin{array}{l}\text { Musala } \\
\text { Rumah } \\
\text { makan } \\
\text { Pongek } \\
\text { Situjuah }\end{array}$ & $\begin{array}{c}293 \\
0\end{array}$ & $1^{0} \mathrm{ke}$ Utara & $\begin{array}{l}\text { Rasdhul } \\
\text { kiblat- } \\
\text { Theodolite }\end{array}$ \\
\hline 2. & $\begin{array}{l}\text { Musala } \\
\text { Rumah } \\
\text { makan } \\
\text { Terang } \\
\text { Bulan } \\
\end{array}$ & $\begin{array}{c}292 \\
0\end{array}$ & $2^{0} \mathrm{ke}$ utara & $\begin{array}{l}\text { Rasdhul } \\
\text { kiblat- } \\
\text { Theodolite }\end{array}$ \\
\hline 3. & $\begin{array}{l}\text { Musala } \\
\text { Rumah } \\
\text { makan } \\
\text { Ombak } \\
\text { Pangkalan }\end{array}$ & $\begin{array}{c}292 \\
0\end{array}$ & $2^{0} \mathrm{ke}$ Utara & $\begin{array}{l}\text { Rasdhul } \\
\text { Kiblat } \\
\text { Theodolie }\end{array}$ \\
\hline 4. & $\begin{array}{l}\text { Musala } \\
\text { Rumah } \\
\text { makan }\end{array}$ & $\begin{array}{c}293 \\
0\end{array}$ & $1^{0} \mathrm{ke}$ utara & $\begin{array}{l}\text { Rasdhul } \\
\text { Kiblat } \\
\text { Theodolie }\end{array}$ \\
\hline
\end{tabular}

${ }^{25}$ Fahmi Fatwa Rosyadi Satria Hamdani Indonesian Journal et al., "Indonesian Journal of

\begin{tabular}{|c|c|c|c|c|}
\hline & Uwan & & & \\
\hline 5. & $\begin{array}{l}\text { Musala } \\
\text { Rumah } \\
\text { makan } \\
\text { Ranah } \\
\text { Minang }\end{array}$ & $\begin{array}{c}290 \\
0\end{array}$ & $4^{0}$ ke Utara & $\begin{array}{l}\text { Rasdhul } \\
\text { Kiblat } \\
\text { Theodolie }\end{array}$ \\
\hline 6. & $\begin{array}{l}\text { Musala } \\
\text { Rumah } \\
\text { makan Aia } \\
\text { Badarun }\end{array}$ & $\begin{array}{c}293 \\
0\end{array}$ & $1^{0} \mathrm{ke}$ Utara & $\begin{array}{l}\text { Rasdhul } \\
\text { Kiblat } \\
\text { Theodolie }\end{array}$ \\
\hline 7. & $\begin{array}{l}\text { Musala } \\
\text { Rumah } \\
\text { makan } \\
\text { Mandeh } \\
\text { Kanduang } \\
\text { (Pesisir } \\
\text { Selatan) }\end{array}$ & $\begin{array}{c}290 \\
0\end{array}$ & $4^{0}$ ke Utara & $\begin{array}{l}\text { Rasdhul } \\
\text { Kiblat } \\
\text { Theodolie }\end{array}$ \\
\hline 8. & $\begin{array}{l}\text { Musala } \\
\text { Rumah } \\
\text { makan } \\
\text { Bunda }\end{array}$ & $\begin{array}{c}293 \\
0\end{array}$ & $1^{0} \mathrm{ke}$ Utara & $\begin{array}{l}\text { Rasdhul } \\
\text { Kiblat } \\
\text { Theodolie }\end{array}$ \\
\hline 9. & $\begin{array}{l}\text { Musala } \\
\text { Rumah } \\
\text { makan } \\
\text { Lamun } \\
\text { Ombak }\end{array}$ & $\begin{array}{c}295 \\
0\end{array}$ & $\begin{array}{ll}1^{0} & \text { ke } \\
\text { Selatan } & \end{array}$ & $\begin{array}{l}\text { Rasdhul } \\
\text { Kiblat } \\
\text { Theodolie }\end{array}$ \\
\hline 10. & $\begin{array}{l}\text { Musala } \\
\text { Rumah } \\
\text { makan } \\
\text { Pasia } \\
\text { Piaman }\end{array}$ & $\begin{array}{c}292 \\
0\end{array}$ & $2^{0}$ ke Utara & $\begin{array}{l}\text { Rasdhul } \\
\text { Kiblat } \\
\text { Theodolie }\end{array}$ \\
\hline 11. & $\begin{array}{l}\text { Musala } \\
\text { Rumah } \\
\text { makan } \\
\text { Umega } \\
\text { Gunung } \\
\text { Medan }\end{array}$ & $\begin{array}{c}294 \\
0\end{array}$ & $0^{0}$ & $\begin{array}{l}\text { Rasdhul } \\
\text { Kiblat } \\
\text { Theodolie }\end{array}$ \\
\hline 12. & $\begin{array}{l}\text { Musala } \\
\text { Rumah } \\
\text { makan Sari } \\
\text { Ratu } \\
\text { Sijunjung } \\
\end{array}$ & $\begin{array}{c}287 \\
0\end{array}$ & $7^{0}$ ke Utara & $\begin{array}{l}\text { Rasdhul } \\
\text { Kiblat } \\
\text { Theodolie }\end{array}$ \\
\hline 13. & $\begin{array}{l}\text { Musala } \\
\text { Rumah } \\
\text { makan } \\
\text { Salero } \\
\text { Kampung }\end{array}$ & $\begin{array}{c}289 \\
0\end{array}$ & $5^{0}$ ke Utara & $\begin{array}{l}\text { Rasdhul } \\
\text { Kiblat } \\
\text { Theodolie }\end{array}$ \\
\hline 14. & $\begin{array}{l}\text { Musala } \\
\text { Rumah } \\
\text { makan } \\
\text { Pondok } \\
\text { Tarapuang }\end{array}$ & $\begin{array}{c}292 \\
0\end{array}$ & $3^{0} \mathrm{ke}$ Utara & $\begin{array}{l}\text { Rasdhul } \\
\text { Kiblat } \\
\text { Theodolie }\end{array}$ \\
\hline 15 & Musala & 292 & $2^{0}$ ke Utara & Rasdhul \\
\hline
\end{tabular}

InterdIsciplinary Islamic Studies" 1, no. 1 (2017), h. 245-62. 


\begin{tabular}{|c|c|c|c|c|}
\hline & $\begin{array}{l}\text { Rumah } \\
\text { makan } \\
\text { kapau } \\
\text { Simpang } \\
\text { Empat } \\
\text { Pasaman } \\
\text { Barat }\end{array}$ & 0 & $\begin{array}{l}\text { Kiblat } \\
\text { Theodolie }\end{array}$ & - \\
\hline 16 & $\begin{array}{l}\text { Musala } \\
\text { Rumah } \\
\text { makan } \\
\text { Angin } \\
\text { Berembus }\end{array}$ & $\underset{0}{283} 11^{0}$ ke Utara & $\begin{array}{l}\text { Rasdhul } \\
\text { Kiblat } \\
\text { Theodolie }\end{array}$ & - \\
\hline 17. & $\begin{array}{l}\text { Musala } \\
\text { Rumah } \\
\text { makan } \\
\text { Pondok } \\
\text { Kita } \\
\text { Darmasray } \\
\text { a }\end{array}$ & $\underset{0}{288} \quad 6^{0}$ ke utara & $\begin{array}{l}\text { Rasdhul } \\
\text { Kiblat } \\
\text { Theodolie }\end{array}$ & - \\
\hline
\end{tabular}

Berdasarkan survei terhadap 17 musala yang ada di Rumah makan pinggir jalan lintas Kabupaten Kota di Sumatera Barat yang ditunjukkan oleh Tabel 4. Dapat diketahui informasi tentang data penelitian astronomis musala di Rumah makan pinggir jalan lintas Kabupaten Kota di Sumatera Barat di antaranya lintas, bujur, arah kiblat, hasil pengukuran penelitian, dan derajat deviasi

Arah hadap musala akurat adalah tepat atau $0^{0}$ sesuai dengan hasil hitungan akurasi arah kiblat. Arah positif (+) bila arah

${ }^{26}$ Sarif M, "Peningkatan Pemahaman Takmir Masjid Di Wilayah Malang Terhadap Penentuan Akurasi Arah Kiblat," Dedikasi 10 (2013), h. 40-44.

27 Mustaqim, "Analisis Metode Penentuan Arah Kiblat Masjid Agung Baitul Makmur Meulaboh Aceh Barat 20 Oktober 2020, h. 24-25:"

${ }^{28}$ Nurul Wakia, "Elfalaky: Jurnal Ilmu Falak Meretas Problematika Arah Kiblat Terkait Salat Di Atas Kendaraan" 4, No. 2 (2020), H. 207-21. hadap musala melebihi hasil hitungan, sedangkan arah negatif (-) jika posisi hadap musala kurang dari hasil hitungan akurasi arah kiblat $^{26}$

Batas toleransi azimut kiblat musala di Rumah makan pinggir jalan lintas Kabupaten Kota di Sumatera Barat

a. Batasan menghadap $\mathrm{Ka}$ 'bah dari daerah Sumatera Barat

Dalam menghadap bangunan Ka 'bah besar rentang sudut yang penulis mengambil dari koordinat batasan Sumatera Barat berdasarkan koordinat lintang yaitu $21^{0} 20^{\prime} 47,33^{\prime \prime} \mathrm{LU}$ dan $39^{\circ}$ 49' 57,14" $\mathrm{BT}^{27}$

Selanjutnya dalam teori toleransi menghadap kiblat penulis menggunakan pendapat Thomas Djamaluddin ${ }^{28}$ di mana beliau menetapkan toleransi untuk menghadap kiblat sebesar $2^{0}$ dari azimut kiblat suatu tempat. ${ }^{29}$, Selain itu dipakai pendapat Ahmad Izzuddin, M.Ag ${ }^{30}$ terkait akurasi metode arah kiblat Toleransi tersebut berdasarkan hadis riwayat baihaqi ${ }^{31}$ bahwa arah kiblat bisa

29 Zainul Arifin, "Toleransi Penyimpangan Pengukuran Arah Kiblat," Elfalaky Jurnal Ilmu Falak 2, no. 1 (2018), h. 62-75

${ }^{30}$ Hendri Institut, Agama Islam, and Negeri Bukittinggi, "Prayer Room Qibla Direction At School In Bukittinggi: (Qibla Study in Junior High School and Senior High Schools Prayer Room)," Journal of Islamic Astronomy 1, no. 1 (2019), h. 24.

31 Fahmi Fatwa Dkk, Pembelajaran Ilmu Falak, "7-Penerapan Model Ctl Dalam Pembelajaran Ilmu Falak" 3 (2016), h.55-69. 


\section{AL-MARSHAD: JURNAL ASTRONOMI ISLAM DAN ILMU-ILMU BERKAITAN ISSN 2442-5729 (print) || ISSN 2598-2559 (online) \\ http://jurnal.umsu.ac.id/index.php/almarshad DOI: //doi.org/10.30596/jam.v7i1.6494 || Vol. 7, No. 1 Juni 2021}

menghadap Ka 'bah, ke arah Masjidil Haram, dan lebih luas lagi menghadap ke arah kota Mekkah ${ }^{32}$

Berdasarkan hal tersebut untuk wilayah Sumatera Barat, yang azimut kiblatnya $295^{\circ}$ daerah Tapan dan $294^{0} 51^{0}$ maka dapat diberikan toleransi menjadi $293^{0}-297^{0}$ dan $292^{0} 15$ $296^{0} 51^{0}$. Berdasarkan perhitungan azimut kiblatnya. ${ }^{33}$. Berikut ini data toleransi arah kiblat yang ditunjukkan oleh Tabel 5.

Tabel 5. Data toleransi arah kiblat

\begin{tabular}{|c|c|c|c|c|}
\hline Titik & $\begin{array}{c}\text { Lintang dan } \\
\text { Bujur }\end{array}$ & $\begin{array}{c}\text { Lintang } \\
\text { Dan } \\
\text { bujur }\end{array}$ & $\begin{array}{c}\text { Azim } \\
\text { ut }\end{array}$ & selisih \\
\hline Utara & $\begin{array}{ll}1^{0} & 20^{\prime}\end{array}$ & Tapan $^{1}=$ & $293^{0} 8$ & $0^{0} 2{ }^{\prime} 34$ \\
\hline \multirow[t]{3}{*}{ Mekah } & 47,33” $\quad \mathrm{LU}$ & $2^{0} 12^{\prime \prime} \mathrm{Ls}$ & $00 "$ & ,6" \\
\hline & dan $39^{\circ} 49^{\prime}$ & dan $101^{0} 5^{,}$ & & \\
\hline & $57,14 ”{ }^{\prime} \mathrm{BT}^{1}$ & BT & & \\
\hline \multirow[t]{4}{*}{ Tengah } & $21^{0}$ & Tapan & $293^{0}$ & 0 \\
\hline & 21,17” LU & $2^{0} 12^{\prime \prime} \quad$ Ls & $06^{\prime}$ & \\
\hline & dan $39^{\circ} 49^{\prime}$ & dan $101^{0}$ & $00 "$ & \\
\hline & $34,56 " \mathrm{BT}$ & $5^{\prime} \mathrm{BT}$ & & \\
\hline \multirow[t]{4}{*}{ Selatan } & $21023^{\prime} 08,56$ & Tapan $=$ & 29300 & $00^{0} 1^{\prime}$ \\
\hline & ”Lu & 2012 Ls & 7’00”' & $00 "$ \\
\hline & $39049^{\prime} 20,06$ & dan & & \\
\hline & "BT & $10105^{\prime} \mathrm{BT}$ & & \\
\hline
\end{tabular}

Arah kiblat musala yang akurat berdasarkan geosentris dihitung dari wilayah Sumatera Barat paling utara yaitu Tapan, maka diketahui untuk batasan toleransi arah kiblatnya berdasarkan

${ }^{32}$ Mushoddik Daulay, Hartono Hartono, and Sunaryo Ishaq, "Akurasi Arah Kiblat Masjid Di perhitungan dan Tabel 5, maka toleransinya sangat kecil yaitu pada hitungan menit yaitu 2 menit busur.

Hasil penelitian yang dilakukan terhadap 17 musala yang ada di Rumah makan pinggir jalan lintas Kabupaten kota di Sumatera Barat, terdapat 2 musala atau $11 \%$ yang tepat arah kiblatnya

1. Arah kilat musala yang tidak akurat, kategori toleransi

Hasil penelitian yang dilakukan terhadap 17 musala yang ada di Rumah makan pinggir jalan lintas kabupaten kota di Sumatera Barat, terdapat 9 musala atau $54 \%$ yang tidak akurat, tetapi dalam kategori toleransi menghadap arah kiblat

2. Arah kiblat musala yang tidak akurat dan di luar toleransi

Hasil penelitian yang dilakukan terhadap 17 musala yang ada di Rumah makan pinggir jalan lintas kabupaten kota di Sumatera Barat, terdapat 6 musala atau $35 \%$ yang tidak akurat dan di luar toleransi menghadap kiblat

\section{Pembahasan}

Pertama, berdasarkan hasil penelitian, diketahui bahwa pemahaman pemilik Rumah makan pinggir jalan lintas Kabupaten Kota di

Kecamatan Bekasi Barat," Jurnal Geografi Edukasi Dan Lingkungan 1, no. 1 (2017), h. 7-18

${ }^{33}$ Zainul Arifin. 


\section{AL-MARSHAD: JURNAL ASTRONOMI ISLAM DAN ILMU-ILMU BERKAITAN \\ ISSN 2442-5729 (print) || ISSN 2598-2559 (online) \\ http://jurnal.umsu.ac.id/index.php/almarshad \\ DOI: //doi.org/10.30596/jam.v7i1.6494 || Vol. 7, No. 1 Juni 2021}

Sumatera Barat kategori tinggi hal ini ditandai dengan metode yang digunakan seperti menggunakan aplikasi arah kiblat pada android, menggunakan kompas, arah kiblat mengarah ke barat dan arah kiblat ditentukan oleh ahlinya namun mayoritas pemilik Rumah makan memahami tidak perlu susah mengukur arah kiblat cukup menggunakan aplikasi arah kiblat pada android $^{34}$. Kemajuan teknologi tentu di satu sisi sangat bermanfaat apalagi dalam beribadah tetapi perlu juga diyakini apakah teknologi tersebut bisa menjamin keakuratan sehingga dapat memenuhi sahnya suatu ibadah terutama ibadah salat dalam menghadap kiblat.

Kedua, terkait dengan metode yang digunakan pemilik Rumah makan pinggir jalan dalam menentukan arah kiblat, dari data di lapangan diketahui bervariasi, namun kebanyakan menentukan arah kiblat dengan menggunakan aplikasi arah kiblat pada android, Untuk aplikasi arah kiblat pada android perlu diketahui tidak semua aplikasi arah kiblat pada android pun tidak semua memiliki akurasi yang baik. ${ }^{35}$

Ketiga, akurasi arah kiblat di musala Rumah makan pinggir jalan lintas kabupaten Kota di Sumatera Barat, berdasarkan teori

34 Wawancara dengan bapak Joni, pemilik Rumah makan Kapau Simpang Empat Pasaman Barat, 10 Oktober 2019, Jam 13.30 Wib dan batasan toleransi menghadap kiblat, maka di kategorikan pada 2 yaitu kategori akurat terdapat 11 musala atau $65 \%$ dan kategori tidak akurat sebanyak 6 musala atau $35 \%$

\section{Kesimpulan}

Penelitian ini menghasilkan kesimpulan, bahwa pemahaman pemilik restoran/ Rumah makan pinggir jalan lintas Kabupaten Kota di Sumatera Barat termasuk kepada pemahaman yang baik. Di mana pentingnya menghadap kiblat ditunjukkan dengan adanya pengukuran di awal pada saat pendirian awal dan juga perawatan lanjutan dengan melakukan pengukuran kembali ketika bangunan di rehab dan di perbaiki. Namun di satu sisi secara keseluruhan pemahaman tentang arah kiblat sudah ada.

Kemudian dari pemahaman yang sudah ada $75 \%$ pemilik Rumah makan pinggir jalan lintas Kabupaten Kota di Sumatera Barat dalam melakukan penentuan arah kiblatnya dengan menggunakan aplikasi arah kiblat berbasis android. Kemudian berdasarkan perhitungan arah kiblat serta pengecekan arah kiblat musala yang ada di Rumah makan pinggir jalan lintas Kabupaten kota di Sumatera Barat yang penulis lakukan dengan menggunakan rumus trigonometri,

${ }^{35}$ M. Ikhtirozun Ni’am, 'Arah Kiblat Di Planet Mars', Al-Marshad: Jurnal Astronomi Islam Dan Ilmu-Ilmu Berkaitan, $2.1 \quad$ (2016), 12-21 <https://doi.org/10.30596/jam.v2i1.762>. 


\section{AL-MARSHAD: JURNAL ASTRONOMI ISLAM DAN ILMU-ILMU BERKAITAN \\ ISSN 2442-5729 (print) || ISSN 2598-2559 (online) \\ http://jurnal.umsu.ac.id/index.php/almarshad \\ DOI: //doi.org/10.30596/jam.v7i1.6494 || Vol. 7, No. 1 Juni 2021}

kompas kiblat, dan metode rashdul kiblat maka diperoleh kesimpulan bahwa deviasi kesalahan arah kiblat paling besar sebanyak $15^{\circ} 21^{\prime} 16^{\prime \prime}$. Hal ini diketahui berdasarkan pada metode yang digunakan oleh pemilik Rumah makan dalam penentuan arah kiblat di musala yang ada di Rumah makan dan restoran pinggir jalan lintas Kabupaten kota di Sumatera Barat

\section{Daftar Pustaka}

Arifin, Nurul, 'Integrasi Teks-Teks Syar'I Yang Terkait Dengan Arah Kiblat Dalam Konteks Astronomi', Elfalaky, $4.1 \quad$ (2020), 73-92 <https://doi.org/10.24252/ifk.v4i1.1416 9>

Arifin, Zainul, 'Toleransi Penyimpangan Pengukuran Arah Kiblat', Elfalaky Jurnal Ilmu Falak, 2.1 (2018), 62-75

Budiwati, Anisah, 'Akurasi Arah Kiblat Masjid Di Ruang Publik', JSSH (Jurnal Sains Sosial Dan Humaniora), 2.1 (2018),

<https://doi.org/10.30595/jssh.v2i1.227 5>

Daud, Mohd. Kalam, and Muhammad Kamalussafir, 'AKURASI ARAH KIBLAT KOMPLEK PEMAKAMAN DITINJAU MENURUT KAIDAH TRIGONOMETRI (Studi Kasus Di Kecamatan Syiah Kuala Kota Banda
Aceh)', SAMARAH: Jurnal Hukum

Keluarga Dan Hukum Islam, 2.2 (2019), 502

<https://doi.org/10.22373/sjhk.v2i2.475 $0>$

Daulay, Mushoddik, Hartono Hartono, and Sunaryo Ishaq, 'Akurasi Arah Kiblat Masjid Di Kecamatan Bekasi Barat', Jurnal Geografi Edukasi Dan Lingkungan, 1.1 (2017), 7-18

Faiz, A B D Karim, 'MODERASI FIQH PENENTUAN ARAH KIBLAT: Akurasi Yang Fleksibel', Of Islamic Law, $\quad 1.1 \quad$ (2020), 83-99 <https://doi.org/10.24260/jil.v1i1.23>

Falak, Pembelajaran Ilmu, '7-Penerapan Model Ctl Dalam Pembelajaran Ilmu Falak', 3 (2016), 55-69

Hamdani, Fahmi Fatwa Rosyadi Satria, Encep Abdul Rojak, Rizka Amalia, Amalia Hutami, and Ummu Rosyidah, 'An Accuracy Test of Qibla Direction Measurement of Mosques and Prayer Rooms', 409.SoRes 2019 (2020), 82-87 <https://doi.org/10.2991/assehr.k.20022 $5.018>$

Herdiansah, Arief, Yani Sugiyani, and Ri Sabti Septarini, 'Penerapan Pembelajaran E-Bisnis Siswa Pkbm Paja Mandiri Pada Pembuatan Prototipe Sistem Rumah Makan Masakan Padang Kutabumi', JIKA (Jurnal Informatika), 


\section{AL-MARSHAD: JURNAL ASTRONOMI ISLAM DAN ILMU-ILMU BERKAITAN \\ ISSN 2442-5729 (print) || ISSN 2598-2559 (online) \\ http://jurnal.umsu.ac.id/index.php/almarshad \\ DOI: //doi.org/10.30596/jam.v7i1.6494 || Vol. 7, No. 1 Juni 2021}

\section{2}

(2020),

$<$ https://doi.org/10.31000/jika.v4i2.262

$1>$

Hosen, Hosen, and Eka Nurhalisa, 'Akurasi

Arah Kiblat Pemakaman Desa Ponteh

Kecamatan Galis Kabupaten

Pamekasan', Al-Marshad: Jurnal

Astronomi Islam Dan Ilmu-Ilmu

Berkaitan, 5.2 (2019), 146-76

<https://doi.org/10.30596/jam.v5i2.379

6>

Institut, Hendri, Agama Islam, and Negeri

Bukittinggi, 'PRAYER ROOM QIBLA DIRECTION AT SCHOOL IN

BUKITTINGGI : (Qibla Study in Junior

High School and Senior High Schools

Prayer Room)', Journal of Islamic

Astronomy, 1.1 (2019)

Journal, The Indonesian, Interdisciplinary

Islamic Studies, Doctoral Program, and

Islamic Law, 'Indonesian Journal of InterdIsciplinary Islamic Studies', 1.1 (2017), 245-62

KHARISMA, ARSYI, and Prima

Sukmadianti Putri, 'Upaya Rumah

Makan Padang Dalam Menciptakan

Kepuasan Pelanggan', 2018

<https://doi.org/10.31219/osf.io/au4fg >

Kimura Soderi, Ridho, 'Al-Marshad: Jurnal

Astronomi Islam Dan Ilmu-Ilmu

Berkaitan', Jurnal Astronomi Islam Dan

Ilmu-Ilmu Berkaitan, 5729.June (2018),
46-66 <https://doi.org/10.30596/jam.v>

Lubis, Sudirman, 'DESIGN OF QIBLAT

DIRECTION USING HMc 5883L

SENSOR', 2 (2021), 178-84

Madia Patra Ismar, 'Rumah Makan Padang

Sebuah Narasi Pertunjukan Budaya:

Studi Kasus Rumah Makan Padang Simpang Raya', Urban, 2.1 (2019), 4147

Mustaqim,hen Riza Afrian, 'Analisis Metode Penentuan Arah Kiblat Masjid Agung Baitul Makmur Meulaboh Aceh Barat Abstract Problems Related to the Accuracy of the Qibla Direction at the Great Mosque of Baitul Makmur Meulaboh, West Aceh Cannot Be Tolerated. The Reason Is, the Level', 6.2 (2020), 181-94 <https://doi.org/10.30596/jam.v>

M. Ikhtirozun Ni'am, 'Arah Kiblat Di Planet Mars', Al-Marshad: Jurnal Astronomi Islam Dan Ilmu-Ilmu Berkaitan, 2.1 (2016),

$<$ https://doi.org/10.30596/jam.v2i1.762 $>$

Nisa, Ulyatun, and Titin Suprihatin, 'Uji Akurasi Aplikasi Sun Qibla Dalam Penentuan Arah Kiblat Praktis', 11-15

Oktavianus, Oktavianus, Ike Revita, and Khairil Anwar, 'Lanskap Linguistik Nilai Budaya Pada Rumah Makan Minang ( Linguistic Landscape of 


\section{AL-MARSHAD: JURNAL ASTRONOMI ISLAM DAN ILMU-ILMU BERKAITAN \\ ISSN 2442-5729 (print) || ISSN 2598-2559 (online) \\ http://jurnal.umsu.ac.id/index.php/almarshad \\ DOI: //doi.org/10.30596/jam.v7i1.6494 || Vol. 7, No. 1 Juni 2021}

Cultural Values at Rumah Makan

Minang )', Mozaik Humaniora, 19.1

(2019), 90-108

Putri, Arsyi Kharisma And Prima

Sukmadianti, 'Upaya Rumah Makan

Padang Dalam Menciptakan Kepuasan

Pelanggan', OSF Preprints, 2018

$<$ https://doi.org/https://doi.org/10.3121

9/osf.io/au4fg>

Reny dkk, 'Strategi Pengembangan Bisnis

Rumah Makan Padang Di Sekitar

Lingkar Kampus Ibi Kosgoro 1957',

Mediastima, 26.1 (2020), 18-25

Salat, Terkait, and D I Atas, 'ELFALAKY :

Jurnal Ilmu Falak Vol. 4. Nomor 2.

Tahun 2020 M / 1441 H MERETAS

PROBLEMATIKA ARAH KIBLAT

TERKAIT SALAT DI ATAS

KENDARAAN', 4.2 (2020), 207-21

Sarif M, 'Peningkatan Pemahaman Takmir

Masjid Di Wilayah Malang Terhadap

Penentuan Akurasi Arah Kiblat',

Dedikasi, 10 (2013), 40-44

Selasi, Dini, 'Jurnal Inklusif: Jurnal

Pengkajian', Jurnal Inklusif, 4.1 (2019),

$33-46$

Trinanda, Yunia Wardi. Abror Abror and

Okki, 'Service Excellent Rumah Makan

Padang Dalam Perspektif Wisata

Islami', International Journal of

Community Service Learning, 3.3

(2019), 133
—, 'Service Excellent Rumah Makan

Padang Dalam Perspektif Wisata

Islami', International Journal of

Community Service Learning, 3.3

(2019), 134

Welsa, Henny, 'Budaya Minangkabau Dan Implementasi Pada Manajemen Rumah Makan Padang Di Yogyakarta', EKUITAS (Jurnal Ekonomi Dan Keuangan), $\quad 1.2 \quad$ (2017), 181 <https://doi.org/10.24034/j25485024.y2 017.v1.i2.2095>

Yunus, Muhammad, 'Hadis Tentang Arah Kiblat: Kritik Pemikiran Ali Mustafa Yaqub', Jurnal Al-Irfani STAI Darul Kamal, VI.1 (2020), 8-17 